\title{
Ultrastructure of the Cornea Epithelium in Keratoconus
}

\author{
By
Mustafa AKTEKIN*, Mustafa F. SARGON**, Pinar ÇAKAR ${ }^{* * *}$, H. Hamdi ÇELIK ${ }^{* * * *}$ and Esin FIRAT ${ }^{* * * *}$

\begin{abstract}
*Research Fellow in Department of Anatomy, Faculty of Medicine, Hacettepe University, Ankara, Turkey
**Assistant Professor in Department of Anatomy, Faculty of Medicine, Hacettepe University, Ankara, Turkey

*** Ophthalmologist in SSK Ankara Eye Hospital, Turkey

****Associate Professor in Department of Anatomy, Faculty of Medicine, Hacettepe University, Ankara, Turkey
\end{abstract} \\ *****Associate Professor in SSK Ankara Eye Hospital, Turkey
}

- Received for Publication, March 23, 1998 -

Key Words: Keratoconus, Corneal epitelium, Electron microscopy

\begin{abstract}
Summary: In this study, 20 keratoconus corneal tissue were examined. In TEM examination of the comea, the epithelium was irregular in thickness. In these epithelial cells, the number of microvilli were decreased and they showed an irregular arrangement. Vesicular degeneration and swelling of the mitochondria were observed in the cytoplasm of these cells. Interepithelial relation was normal and the desmosomes did not show any pathology. In the electron microscopic examination of the stroma, focal degeneration was observed in the collagen fibers. In SEM examination of the cornea, depressions and elevations were found on the epithelial surface. Additionally, degenerated epithelial cells were observed on focal areas. To our knowledge, the decreased number of microvilli and their irregular arrangement which we observed in TEM examination of the cornea epithelium were not reported in the literature.
\end{abstract}

Keratoconus is a corneal dystrophy that is characterized by central or paracentral stromal thinning and conical deformity that causes aberrations in the refraction at those sites. It is also defined as a noninflammatory protrusion of the cornea. As many other corneal dystrophies, keratoconus presents in the first decades of life ${ }^{1)}$ but the transparency of the corneal stroma remains for a long time. It is usually bilateral and more common in Mediterranean region $^{2)}$. The etiology in keratoconus is unknown but hereditary factors ${ }^{3-5)}$, repeated eye traumas or contact lens wearing ${ }^{2,6,7)}$ may play roles. Many accompanying systemic or ocular diseases may exist such as Down syndrome ${ }^{8)}$, Marfan syndrome ${ }^{9)}$, atopic dermatitis ${ }^{10,11)}$, vernal catarrh. ${ }^{12)}$, retinal degeneration ${ }^{13)}$. The earliest changes occur in Bowman's layer as irregular thickness. Also the epitelium is irregular in thickness and shows an abnormal basement membrane ${ }^{14}$. Although many studies concerning the amount of collagen fibers within the stroma have made different comments so far, it is shown that the amount of collagen fibers is diminished. The aim of this study is to evaluate the epithelium and the stroma in keratoconus with TEM and SEM.

\section{Materials and Methods}

20 Corneal tissues were removed by PKP(penetrating keratoplast) at SSK Ankara Eye Hospital. For TEM examination; the specimens were fixed in $2.5 \%$ gluteraldehyde for 24 hours, washed in Sorenson's phosphate buffer (ph:7.4), post-fixed in $1 \%$ osmium tetroxide in phosphate buffer (ph:7.4) and dehydrated in increasing concentrations of alcohol. Then, the tissues were washed with propylene oxide and embedded in epoxy-resin embedding media. Ultra-thin sections about $60 \mathrm{~nm}$ in thickness were cut with a glass knife on a LKB-Nova (Sweden) ultramicrotome and were collected on copper grids, stained with uranyl acetate and lead citrate and examined with a Jeol JEM 1200 EX (Japan) transmission electron microscope. For SEM examination; the same steps were followed until the post-fixation with $1 \%$ osmium tetro-

Correspondence to: Mustafa Aktekin, M.D., Department of Anatomy Faculty of Medicine, Hacettepe University, 06100, Ankara, Turkey 
xide and the specimens were dehydrated with aceton and critical-point dried. Then the specimens were covered by gold in $100 \mathrm{~A}^{0}$ thickness and examined by Jeol SEM-ASID 10 scanning electron microscope.

\section{Results}

In transmission electron microscopic examination of the cornea, the epithelium was irregular in thickness. In these epithelial cells, the number of microvilli were decreased and they showed an irregular arrangement (Fig. 1). Vesicular degeneration and swelling of the mitochondria were observed in the cytoplasm of these corneal epithelial cells (Fig. 2). Interepithelial relation was normal and the desmosomes did not show any pathology (Fig. 3). In the electron microscopic examination of the stroma, focal degeneration was observed in the collagen fibers (Fig. 4).

In the scanning electron microscopic examination of the cornea, the conical deformity (Fig. 5), depressions and elevations were observed on the epithelial surface (Fig. 6). Additionally, degenerated epithelial cells were observed on focal areas (Fig. 7).

\section{Discussion}

Jongebloed et al. found abnormally shaped, deformed polygonal cells in the epithelium of the cornea of a patient with keratoconus. Also, the cells were found missing nuclei, while the cell membranes were intact. ${ }^{15)}$ In another study, Tsubota et al. reported that the epithelial cells were enlarged in the patients with keratoconus. ${ }^{16)}$

In our study we observed degenerated epithelial cells with intact cell membranes in focal areas and all the epithelial cells had regularly shaped nuclei (Fig. 8). Abnormally shaped, deformed polygonal cells were not seen in our samples. Additionally, the decreased number of microvilli and their irregular arrangement which we observed in TEM examination of the cornea epithelium were not reported in the literature. As a result, the severity of the disease may change the ultrastructural findings and this fact must be taken into consideration while examining the cornea samples in keratoconus.

\section{References}

1) Kennedy RH, Bourne WM and Dyer JA. A 48-year clinical and epidemiologic study of keratoconus. Am J Ophthalmol 1986; 101:267-273.

2) Pouliquen Y. Doyne Lecture Keratoconus. Eye 1987; 1:114.

3) Waardenburg PJ, Franceschetti A and Klein D. Genetics and ophthalmology. Springfield Charles C Thomas 1961; 452-456.

4) Hallermann W and Wilson EJ. Genetische betrachtrungen uber den keratokonus. Klin Monatsbl Augenheilkd 1977; 170:906-908.

5) Hammerstein W. Zur genetik des keratokonus. A. V. Graefes. Arch Klin Exp Ophthal 1974; 190:293-308.

6) Gasset AR, Houde WL and Garcia- Bengochea M. Hard contact lens wear as an environmental risk in keratoconus. Am J Ophthalmol 1978; 85:339-341.

7) Matsuda MM, MacRae SM, Inaba $M$ and Manabe $R$. The effects of hard contact lens wear on the keratoconic corneal endotelium after penetrating keratoplasty. Am J Ophthalmol 1989; 107:246-251.

8) Walsh SZ. Keratoconus and blindness in 469 institutionalized subjects with Down syndrome and other causes of mental retardation. J Ment Defic Res 1981; 25:243-251.

9) Maumenee IH. The eye in the Marfan syndrome. Trans Am Ophthalmol Soc 1981; 79:684-733.

\section{Explanation of Figures}

Plate I

Fig. 1. Electron micrograph showing the irregularity in the thickness of the epithelium (arrow). The number of microvilli were decreased and they showed an irregular arrangement in these cells $\left(^{*}\right)$ (Original magnification $\times 10000$ ).

Fig. 2. Electron micrograph showing the vesicular degeneration (arrow) and swelling of the mitochondria (m) (Original magnification $\times 10000$ ). 

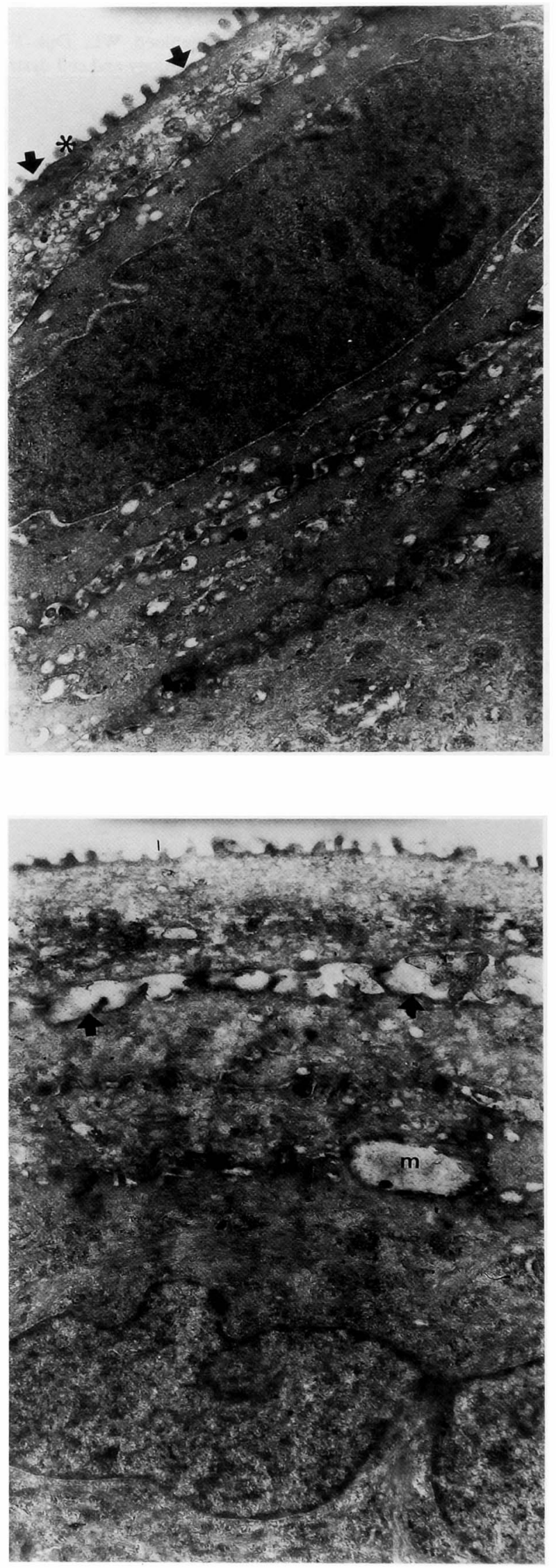
10) Spencer WH and Fisher JJ. The association of keratoconus with atopic dermatitis. Am J Ophthalmol 1959; 47:332-334.

11) Monckton Copeman PW. Eczema and keratoconus. $\mathrm{Br}$ Med J 1965; ii:977-979.

12) Tabbara KF and Butrus SI. Vernal conjunctivitis and keratoconus. Am J Ophthalmol 1983; 95:704-705.

13) Maguire LJ and Meyer RF. Ectatic Corneal Degenerations: in New York. Churchill Livingstone. Kaufmann HE, Barron BA, McDonald MB, Waltman SR (eds):The Cornea 1988; 485-498.
14) Polack FM. Contributions of electron microscopy to the study of corneal pathology. Survey of Ophthalmology 1976; 20:393-395.

15) Jongebloed WL, Dijk F and Worst JGF. Keratoconus morphology and cell dystrophy: A SEM study. Doc Opthal 1989; 72:403-409.

16) Tsubota $\mathrm{K}$, Mashima $\mathrm{Y}$, Murata $\mathrm{H}$, Sato $\mathrm{N}$ and Ogata $\mathrm{T}$. Corneal epithelium in keratoconus. The Cornea 1995; 14(1):77-83.

Plate II

Fig. 3. Electron micrograph showing the normal interepithelial relation and desmosomes (arrow) (Original magnification $\times 7500$ ).

Fig. 4. Electron micrograph showing focal degeneration $\left(^{*}\right)$ in the collagen fibers of the stroma (Original magnification $\times 15000$ ). 
Plate II
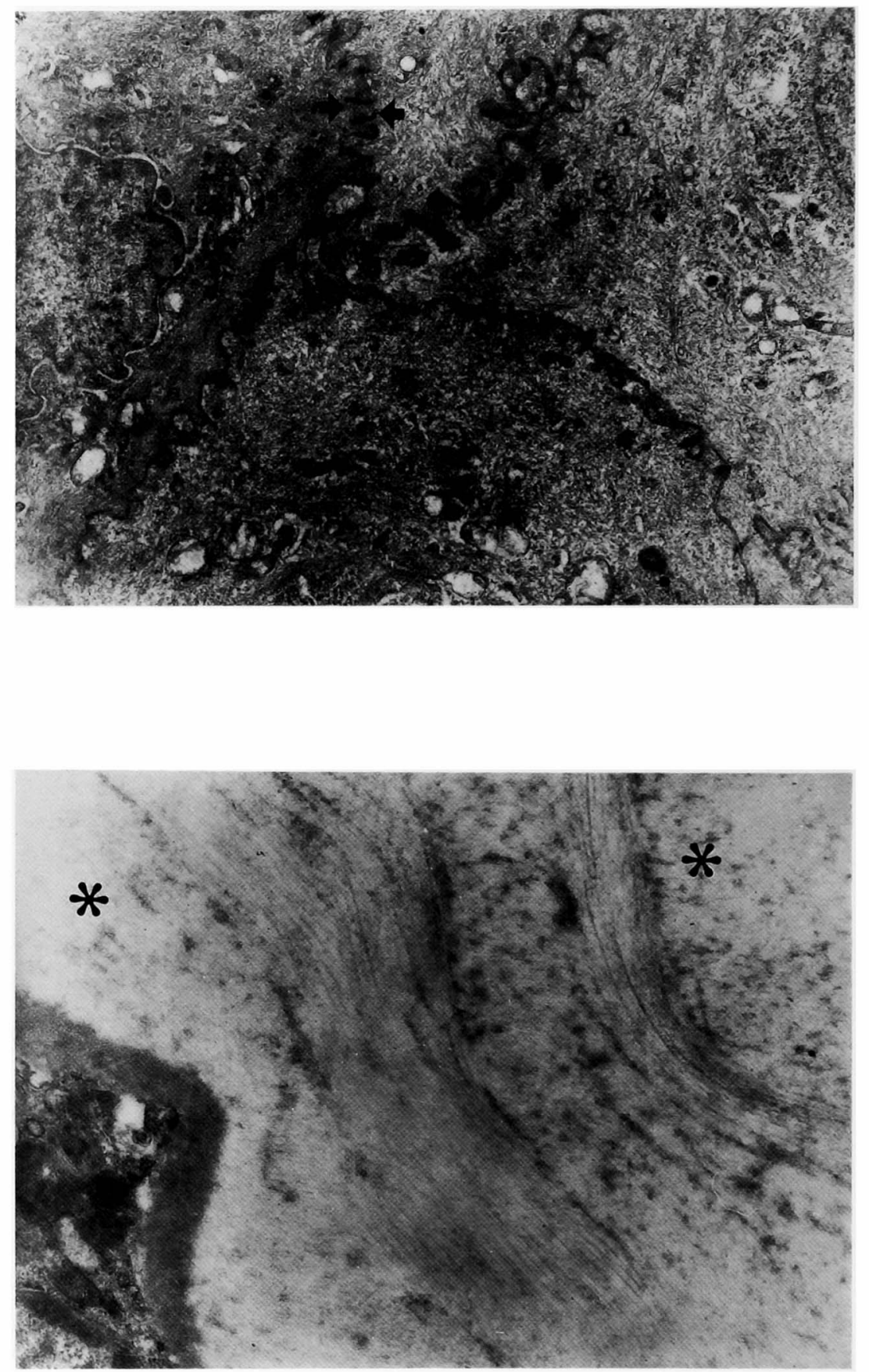


\section{Plate III}

Fig. 5. Electron micrograph showing the conical deformity of the cornea in keratoconus (arrow) (Original magnification $\times 500$ ).

Fig. 6. Electron micrograph showing the depressions (d) and elevations (e) of the epithelial surface (Original magnification $\times 200$ ). 
Plate III
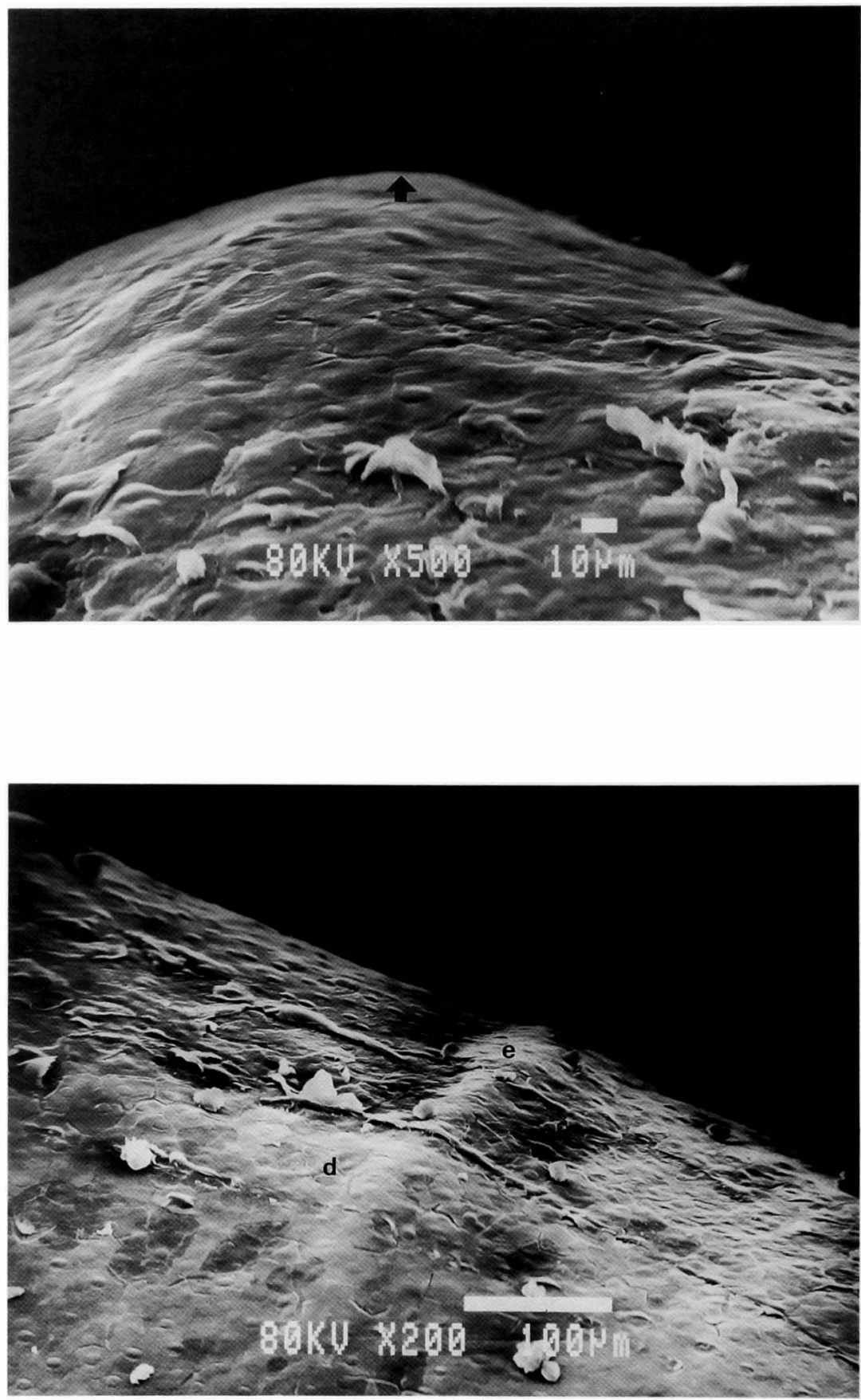


\section{Plate IV}

Fig. 7. Electron micrograph showing the degenerated epithelial cells (arrow) in focal areas (Original magnification $\times 1000$ ).

Fig. 8. Electron micrograph showing the regularly shaped nuclei $(n)$ of the epithelial cells (Original magnification $\times 1500$ ). 
Plate IV
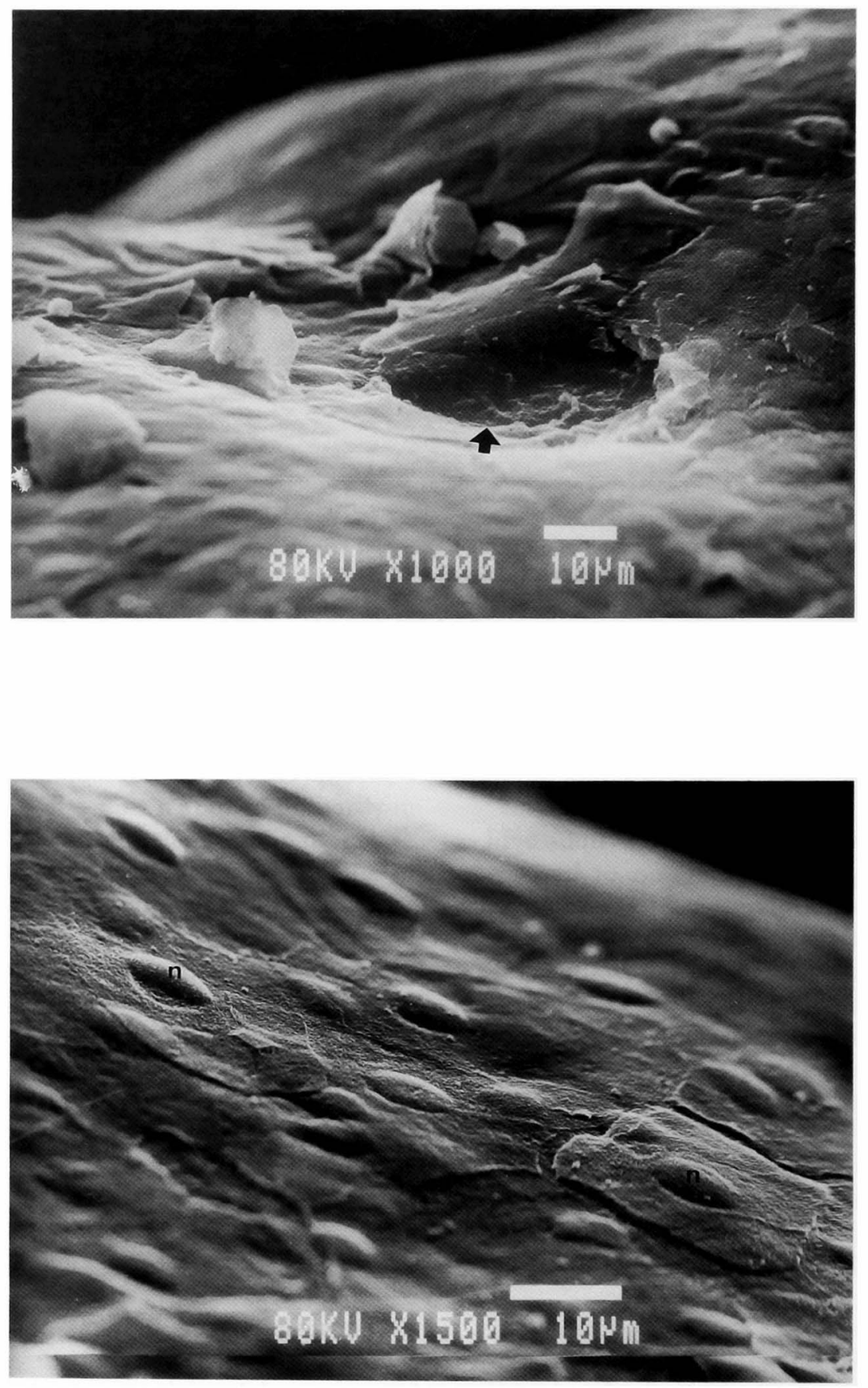